\title{
Comparison of the hemodynamic effects of etomidate between hypertensive and normotensive patients
}

\author{
Hipertansif ve normotansif hastalarda etomidatın hemodinamik etkilerinin karşılaştırılması
}

Hayrettin Daşkaya ${ }^{1}$, Sinan Uzman², Taner Çiftçi ${ }^{3}$, Yavuz Gün ${ }^{4}$, Mehmet Toptaş ${ }^{2}$, Mustafa Demir ${ }^{5}$, Ferda Yılmaz İnal ${ }^{1}$

\begin{abstract}
Objective: Comparison of the hemodynamic effect of etomidate induction in normotensive and hypertensive patients.

Methods: Forty ASA 1-2 patients were included. After informed consent were obtained, patients were divided into two group; Group H: Hypertensive patients, Group $\mathrm{N}$ : Normotensive patients. Fentanile and midazolam were administrated for premedication. Anesthesia induction was performed by etomidate $0.3 \mathrm{mg} / \mathrm{kg}$ and rocuronium $0.6 \mathrm{mg} / \mathrm{kg}$. Arterial pressures and heart rates were measured at certain intervals: control, pre-intubation and 1, 3 and 5 min post-intubation. Myoclonic movements and hemodynamic parameters were noted by an anesthetist who was masked to the groups.
\end{abstract}

Results: Hemodynamic parameters were higher in hypertensive patients but were in clinically tolerable limits.

Conclusion: No hemodynamic instability was observed in anesthesia induction with etomidate in neither hypertensive nor normotensive patients. J Clin Exp Invest 2014; 5 (2): 164-168

Key words: hemodynamic effect, etomidate, hypertension, normotension

\section{INTRODUCTION}

Hypertension is the most prevalent cardiovascular disorder, affecting approximately 1 billion individuals all around the world [1]. During anesthesia, most patients experience periods of hemodynamic instability, which healthy individuals can tolerate, but are usually catastrophic in hypertensive patients due to

\section{ÖZET}

Amaç: Etomidat ile anestezi indüksiyonunun hipertansif ve normotansif hastalarda hemodinamik etkilerini karşılaştırmayı amaçladık.

Yöntemler: Etik komite onayı ve hastaların yazılı ve sözlü onamları alındıktan sonra genel anestezi altında çeşitli elektif cerrahi girişim uygulanacak olan 40 ardışık ASA I-II hasta çalışmaya alındı. Hastalar rastgele 2 gruba ayrıldı: Grup H (Hipertnasif hastalar), Grup N (Normotansif hastalar). Hastalar anestezi indüksiyonundan önce fentanil ve midazolam ile premedike edildi. Anestezi indüksiyonu etomidat $0.3 \mathrm{mg} / \mathrm{kg}$ ve rokuornyum $0.6 \mathrm{mg} / \mathrm{kg}$ ile yapıldı. Arteriyal basınçlar ve kalp hızı şu zamanlarda ölçüldü: kontrol, entübasyon öncesi ve entübasyondan 1, 3, 5 dakika sonra. Grup ayrımından habersiz bir anestezist tarafından miyoklonik hareketler ve hemodinamik parametreler kaydedildi.

Bulgular: Hemodinamik parametreler tüm dönemlerde hipertansif hastalarda daha yüksekti fakat kabul edilebilir klinik sınırlar içindeydi.

Sonuç: Ne hipertansif ne de normotansif hastalarda anestezi indüksiyonunda etomidatla hemodinamik instabilite yoktu.

Anahtar kelimeler: Hemodinamik etki, etomidat, hipertansiyon, normotansiyon

the wide pressure fluctuations and sympathetic hyperactivity.[1] Hypertension, especially when it is not treated, increases the risk of cardiovascular changes during the anesthetic-surgical procedure. On the other hand, pharmacological treatment of this condition is associated with possible interactions with anesthetic and adjuvant drugs.[2] Besides, hypertensive individuals represent a challenge to the

${ }^{1}$ Bezmialem Vakif University, Department of Anesthesiology and Reanimation, Istanbul, Turkey

${ }^{2}$ Haseki Training and Research Hospital, Department of Anesthesiology and Reanimation, Istanbul, Turkey

${ }^{3}$ Dicle University Medical Faculty, Department of Anesthesiology and Reanimation, Diyarbakir, Turkey

${ }^{4}$ Izmir Tepecik Training and Research Hospital, Department of Anesthesiology and Reanimation, Izmir, Turkey

${ }^{5}$ Izmir Atatürk Training and Research Hospital, Department of Gynecology and Obstetrics, Izmir, Turkey

Correspondence: Hayrettin Daşkaya,

Dept. Anesthesiology and Reanimation, Bezmialem Vakif University, Istanbul, Turkey Email: h.daskaya@gmail.com

Received: 13.11.2013, Accepted: 24.04.2014

Copyright @ JCEI / Journal of Clinical and Experimental Investigations 2014, All rights reserved 
professionals involved with perioperative medicine because target-organ compromise (heart, brain, and kidneys), associated with variable functional changes, contribute to the increase in cardiac risk [3].

Etomidate is a carboxylated imidazole-containing anesthetic compound (R-1-ethyl-1-[a-methylbenzyl] imidazole-5-carboxylate) that is structurally unrelated to any other IV anesthetic [4]. Etomidate, a potent, short-acting hypnotic, was introduced into clinical anesthesia in 1973 [5]. Etomidate has an onset of action of 3-5 min, with a peak effect of 1 minute and duration of 3-5 minutes [6]. Etomidate is widely used because it causes minimal cardiorespiratory depression even in the presence of cardiovascular and pulmonary disease [7]. The drug does not induce histamine release and can be safely used in patients with reactive airway disease. Consequently, etomidate is considered to be the induction agent of choice for poor-risk patients with cardiorespiratory disease, as well as in those situations in which preservation of a normal blood pressure is crucial [4].

In the present study, we aimed to compare hemodynamic effects of etomidate used during anesthesia induction on normotensive and hypertensive patients whose blood pressure is regulated with anti-hypertension medication.

\section{METHODS}

\section{Study design}

This study was approved by the local Institutional Review Board. Written informed consent was obtained from all subjects, a legal surrogate, the parents or legal guardians. The study is conducted on 40 patients in ASA Class I-II scheduled to go through various elective surgical operations under general anesthesia. Study is planned as prospective, randomized and double blind. Patients are separated into two groups, Group $\mathrm{H}(\mathrm{n}=20)$ consisted of patients with treated hypertension and Group $N(n=20)$ consisted of normotensive patients. Following 5 minute stabilization in operation room systolic blood pressure (SBP), diastolic blood pressure (DBP), average blood pressure (ABP) and heart rates (HR) of patients are measured and recorded as base values.

Patients with untreated or not regulated hypertension, patients having a base blood pressure outside 100/50 and 160/110 limits, patients with unstable coroner arterial diseases or heart insuffi- ciency, with diabetes mellitus, pheochromocytoma, surrenal cortex insufficiency or any other endocrine anomaly, patients who are more than $\% 30$ over their ideal body weight, patients with a probability of difficult intubation and patients with a known oversensitivity against etomidate are not included in the study.

\section{Induction of anesthesia}

Before the induction of anesthesia all patients were given intravenously $1-1.5 \mathrm{mg}$ of midazolam and 1 $\mu \mathrm{g} / \mathrm{kg}$ 's of fentanyl for premedication. After administering $0.3 \mathrm{mg} / \mathrm{kg}$ etomidate within 20 seconds for induction of anesthesia, muscle relaxation is achieved with $0.6 \mathrm{mg} / \mathrm{kg}$ of rocuronium and endotracheal intubation is performed after 2 minutes. A mask ventilation with $\mathrm{O}_{2}$-air mixture including $\% 50$ $\mathrm{O}_{2}$ is applied until intubation. After endotracheal intubation maintenance of anesthesia is realized by administering sevoflurane at $\% 2$ concentration in a $50: 500_{2}$ /air mixture with a flow rate of $4 \mathrm{lt} /$ minutes.

\section{Outcome parameters}

Hemodynamic parameters are measured and recorded after admitting patients to operation room (control), before etomidate injections, right before intubation and 1, 3, 5, 10, 20, 30, 40 and 50 minutes after intubation.

\section{Statistical analyses}

Data were analyzed using the NCSS (Number Cruncher Statistical System) 2007 \& PASS 2008 Statistical Software (Utah, USA). All differences associated with a chance probability of .05 or less were considered statistically significant. Continuous variables are presented as mean plus minus standard deviation. Parametric tests were applied to data of normal distribution and non-parametric tests were applied to data of questionably normal distribution. Independent-samples t-test was used to compare independent groups. Independent-samples t-test and Mann-Whiney U-test were used to compare independent groups. Comparison between data subsets with a normal distribution were performed using one-way analysis of variance followed by Bonferroni post hoc procedures. Comparison between data subsets with a not-normal distribution were performed using Friedman's non-parametric test. When significant differences were detected, a Wilcoxon signed-ranks test (two-tailed) was used to specify which group differed. 


\section{RESULTS}

There was no statistically significant difference between groups with respect to length, weight and body mass index values $(p>0.05)$. In the hypertension group, number of cases with a ASA score of 2 , were significantly more than normotensive group $(p>0.001)$. Mean age of hypertensive group patients was significantly higher compared to normotensive group $(p<0.001)$ (Table 1).

Table 1. Demographic and clinical data of the study population

\begin{tabular}{lccc}
\hline & $\begin{array}{c}\text { Hypertensive } \\
(\mathrm{n}=20)\end{array}$ & $\begin{array}{c}\text { Normotensive } \\
(\mathrm{n}=20)\end{array}$ & $p$ Value \\
\hline Male/ Female & $8 / 12$ & $8 / 12$ & 1.00 \\
Age (years) & $55.00 \pm 11.77$ & $41.84 \pm 12.16$ & 0.001 \\
BMI $\left(\mathrm{kg} / \mathrm{m}^{2}\right)$ & $26.88 \pm 4.66$ & $25.72 \pm 5.20$ & 0.461 \\
\hline
\end{tabular}

Systolic blood pressure values of hypertensive group from start to 30 minutes were significantly higher compared to normotensive group $(p<0.01$ and $p<0.001)$. In the hypertension group systolic blood pressure values before etomidate, before intubation and after 5, 10, 20, 40 and 50 minutes were significantly reduced compared to values at the start $(p<0.05, p<0.01$, and $p<0.001$, respectively). In the normotensive group systolic blood pressure values at $3 ., 5$. and 10 . minutes were meaningfully reduced compared to the start values $(p<0.001)$. Systolic blood pressure values at $1^{\text {st }}$ minute were significantly higher than start values $(p<0.01)$. In the hypertension group, mean diastolic blood pressure values were significantly higher compared to normotensive group at all intervals except for the values at 40 . and 50 . minutes $(p<0.05, p<0.01$, and $p<0.001$, respectively). In the hypertension group, diastolic blood pressure values before etomidate and before intubation were significantly reduced compared to start values $(p<0.001)$. Diastolic blood pressure values at $1^{\text {st }}$ minute were meaningfully higher compared to start values ( $p<0.01$ for $1^{\text {st }} \mathrm{min}$ ). In the normotensive group, diastolic blood pressure values were significantly reduced compared to start values before etomidate between 5., 10. and 50 . minutes.

Mean blood pressure values for the hypertensive group before etomidate, before intubation and at $10 ., 20$, and 50 . minutes were significantly reduced compared to baseline values $(p<0.05$, $p<0.01$, and $p<0.001$, respectively) (Figure 1 ). In the normotensive group mean blood pressure values before etomidate, before intubation and at 3 ., 5 . and 10. minutes were significantly reduced compared to start values $(p<0.05$ for 3.min), $(p<0.01$ for $5 . \mathrm{min})$, and ( $<<0.001$ for $10 . \mathrm{min})$, respectively. Mean blood pressure values after 1 . minute is significantly higher relative to baseline values $(p<0.01$ for 1.min).

There was no statistically significant difference between groups with respect to heart rate $(p>0.05)$ (Figure 2). In the hypertensive group heart rate values before intubation were significantly reduced compared to start values $(p<0.05)$. In the normotensive group, heart rate values at 10 . and 20 . minutes were significantly reduced compared to start values $(p<0.05$ for 10.min) and ( $p<0.01$ for 20.min).

Table 2. Systolic and diastolic arterial pressures between hypertensive and normotensive groups

\begin{tabular}{|c|c|c|c|c|c|c|}
\hline & \multicolumn{3}{|c|}{ Systolic Arterial Pressure } & \multicolumn{3}{|c|}{ Diastolic Arterial Pressure } \\
\hline & $\begin{array}{l}\text { Hypertensive } \\
(n=20)\end{array}$ & $\begin{array}{c}\text { Normotensive } \\
(n=20)\end{array}$ & $p$ Value & $\begin{array}{l}\text { Hypertensive } \\
(n=20)\end{array}$ & $\begin{array}{c}\text { Normotensive } \\
(n=20)\end{array}$ & $p$ Value \\
\hline Control & $162.40 \pm 14.29$ & $130.50 \pm 12.03$ & 0.0001 & $94.10 \pm 10.54$ & $79.05 \pm 9.17$ & 0.0001 \\
\hline Before etomidate & $152.50 \pm 13.15$ & $126.75 \pm 9.91$ & 0.0001 & $88.70 \pm 8.02$ & $74.45 \pm 8.85$ & 0.0001 \\
\hline Before intubation & $145.85 \pm 13.82$ & $127.35 \pm 10.76$ & 0.0001 & $84.85 \pm 10.83$ & $74.85 \pm 10.65$ & 0.005 \\
\hline 1. $\min$ & $174.75 \pm 25.80$ & $146.00 \pm 24.51$ & 0.001 & $109.20 \pm 17.58$ & $98.65 \pm 15.20$ & 0.049 \\
\hline 3. $\min$ & $155.20 \pm 24.55$ & $114.60 \pm 16.82$ & 0.0001 & $95.55 \pm 14.05$ & $75.45 \pm 10.68$ & 0.0001 \\
\hline 5. $\min$ & $148.00 \pm 22.54$ & $107.85 \pm 13.02$ & 0.0001 & $96.10 \pm 16.85$ & $71.80 \pm 10.71$ & 0.0001 \\
\hline 10. $\min$ & $139.80 \pm 22.01$ & $108.25 \pm 15.37$ & 0.0001 & $91.80 \pm 15.40$ & $75.80 \pm 16.42$ & 0.003 \\
\hline 20. $\min$ & $143.65 \pm 25.02$ & $123.50 \pm 16.74$ & 0.005 & $94.10 \pm 14.27$ & $78.45 \pm 9.62$ & 0.0001 \\
\hline 30. $\min$ & $152.78 \pm 28.20$ & $128.05 \pm 17.80$ & 0.002 & $100.94 \pm 18.88$ & $86.30 \pm 15.82$ & 0.013 \\
\hline 40. $\min$ & $139.12 \pm 19.38$ & $132.53 \pm 16.25$ & 0.291 & $88.76 \pm 16.20$ & $91.88 \pm 15.18$ & 0.574 \\
\hline 50. $\min$ & $137.55 \pm 16.10$ & $130.56 \pm 11.97$ & 0.207 & $92.18 \pm 11.29$ & $87.07 \pm 10.45$ & 0.253 \\
\hline
\end{tabular}




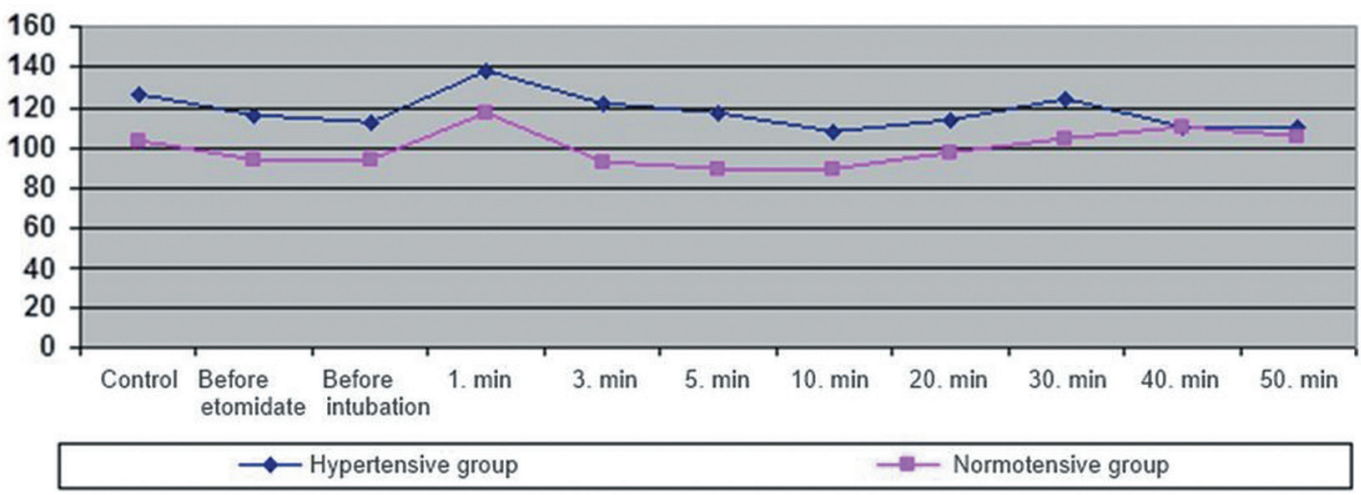

Figure 1. Mean arterial pressure values between hypertensive and normotensive groups. In the normotensive group, heart rate values at 10 . min. $(p<0.05)$ and 20. min. $(p<0.01)$ were significantly reduced compared to start values

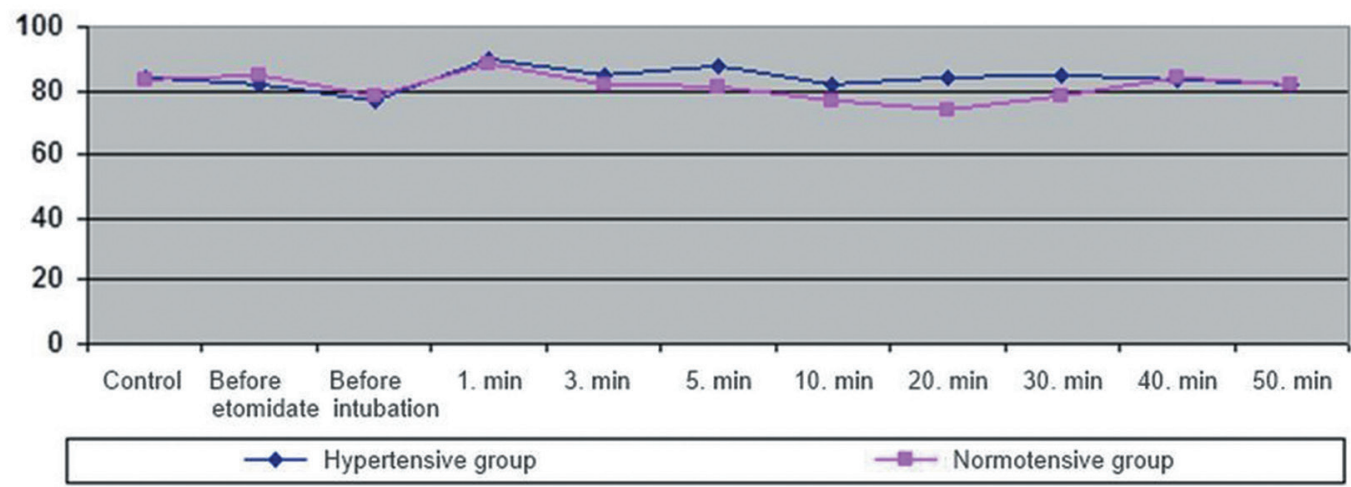

Figure 2. Mean heart rate values between hypertensive and normotensive groups. There was no statistically significant difference between groups with respect to heart rate $(p>0.05)$

\section{DISCUSSION}

Since this is a study on hemodynamic variations during anesthetic induction, when several factors could affect the results, detailed inclusion and exclusion criteria were followed to improve methodological quality and minimize systematic errors. The groups being compared had similar demographic and hemodynamic characteristics, especially regarding the Mallampati index and physical status ASA. A possible confounding bias represented by hypoxemia, which increases blood pressure and heart rate, was ruled out by the determination of the oxygen saturation of hemoglobin during anesthetic induction, and it remained above $97 \%$ throughout the study [8].

The results we obtained from our study revealed that mean arterial blood pressure values during the 30 minute interval after anesthesia induction with etomidate in hypertensive patients are higher than normotensive patients in a statistically significant way. High base blood pressure values in hypertensive patients can be one of the possible reasons for this difference. Systolic blood pressure control values for hypertensive and normotensive patients was $162.4 \pm 14.29 \mathrm{mmHg}$ and $130.5 \pm 12.0$ $\mathrm{mmHg}$, respectively. A study by Onat et al. showed that blood pressure is fully controlled in $\% 58$ of patients who are treated with anti-hypertension medication (blood pressure $<140$ and/or $<90 \mathrm{mmHg}$ ) and for $\% 24$ of those patients blood pressure is reduced to light hypertension levels (blood pressure 140159 and/or 90-94 mmHg) or kept at these levels [9]. In our study, although arterial blood pressure values of patients were measured to be below 160/90 $\mathrm{mmHg}$ measurements in the operation room gave higher values.

In a study conducted by Singh et al. to research hemodynamic effects of different induction agents on cardiovascular surgery patients after anesthesia induction with $0.2 \mathrm{mg} / \mathrm{kg}$ etomidate, important reductions in mean blood pressure, stroke volume index and cardiac index values were reported [10]. Additionally an increase in systemic vascular resistance and central venous pressure was observed. 
These reductions in hemodynamic parameters were thought to be possibly related to $4 \mu / \mathrm{kg}$ fentanyl dose administered before etomidate. In our study, while the reductions in systolic and diastolic blood pressures of normotensive group after induction with etomidate were at insignificant levels, the reductions in hypertensive group were statistically significant but not at a meaningful level clinically. Compared to control values no reduction of more than $10 \%$ in average has occurred. In the normotensive group these reductions were around $3-5 \mathrm{mmHg}$ average. Compared to the study done by Sing, having a lower fentanyl dose $(4 \mu / \mathrm{kg}$ vs. $1 \mu / \mathrm{kg})$ and the absence of non-cardiac surgery on our patients are thought to be the reason for this difference [10].

Zhang et al. reported a reduction of $4 \mathrm{mmHg}$ only in systolic and diastolic blood pressures for a patient group on which $1 \mu / \mathrm{kg}$ fentanyl was administered together with etomidate [11].However, in blood pressure values measured during endotracheal intubation and 1 minute after intubation significant increases up to \%25 was observed. However these increases were within clinically accepted limits. While the mean systolic blood pressure values before operation and during intubation was $24 \pm 10$ $\mathrm{mmHg}$ and $153 \pm 13 \mathrm{mmHg}$ respectively, for mean diastolic blood pressures these values were $4 \pm 12$ $\mathrm{mmHg}$ and $89 \pm 13 \mathrm{mmHg}$. Similarly in our study, increases 1 minute after intubation in normotensive and hypertensive groups dropped below control values within 3 minutes. Increases were within clinically acceptable limits.

In conclusion, after anesthesia induction with etomidate although arterial blood pressures were observed to be higher compared to normotensive group, in light of the results we obtained from our study we have concluded that anesthesia induction with etomidate can be safely applied on hyperten- sive patients and does not result in hemodynamic instability.

\section{REFERENCES}

1. Joint National Committee. The Seventh Report of the Joint National Committee on Prevention, Detection, Evaluation, and Treatment of High Blood Pressure. National Institutes of Health, 2003.

2. Hanada S, Kawakami H, Goto T, Morita S. Hypertension and anesthesia. Curr Opin Anaesthesiol 2006;19:315-319.

3. Hassan MA, Prys-Roberts C. Anesthesia and chronic hypertension. Middle East J Anesthesiol 1991;11:119146.

4. Barash PG, Cullen BF, Stoelting RK. Clinical Anesthesia, $5^{\text {th }}$ Ed; Philadelphia; Lippincott Williams \& Wilkins, 2006; p. 344-345.

5. Doenicke A. Etomidate, a new intravenous hypnotic. Acta Anaesthesiol Belg 1974;25:307-315.

6. Wolfson AB. Harwood-Nuss' Clinical Practice of Emergency Medicine, 4th Ed; Portland; Lippincott Williams \& Wilins, 2005; p. 1150-1153.

7. Gooding JM, Weng JT, Smith RA, et al. Cardiovascular and pulmonary response following etomidate induction of anesthesia in patients with demonstrated cardiac disease. Anesth Analg 1979;058:40-41.

8. Forbes AM, Dally FG. Acute hypertension during induction of anaesthesia and endotracheal intubation in normotensive man. Br J Anaesth 1970;42:618-624.

9. Onat A. Risk factors and cardiovascular disease in Turkey. Atherosclerosis 2001;156:1-10

10. Singh R, Choudhury M, Kapoor PM, Kiran U. A randomized trial of anesthetic induction agents in patients with coronary artery disease and left ventricular dysfunction. Ann Card Anaesth 2010;13:217-223.

11. Zhang GH, Sun L. Peri-intubation hemodynamic changes during low dose fentanyl, remifentanil and sufentanil combined with etomidate for anesthetic induction. Chin Med J 2009;122:2330-2334. 